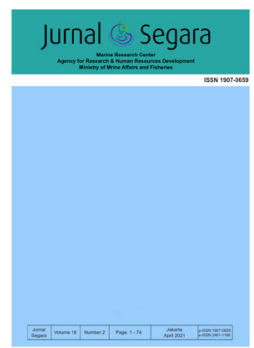

JURNAL SEGARA

http://ejournal-balitbang.kkp.go.id/index.php/segara

ISSN : 1907-0659

e-ISSN : 2461-1166

Accreditation Number: 766/AU3/P2MI-LIPI/10/2016

\title{
ASSESSMENT OF UNDERGROUND WATER QUALITY IN KARIMUNJAWA ISLAND, CENTRAL JAVA - INDONESIA
}

\author{
Joko Prihantono1), Yulius"), Semeidi Husrin"1), Muhammad Ramdhan'), \& Wisnu A. Gemilang2) \\ ${ }^{1)}$ Marine Research Centre, Ministry of Marine Affairs and Fisheries, Indonesia \\ ${ }^{2)}$ Research institute of coastal resources and vulnerability, Ministry of Marine Affairs and Fisheries, Indonesia
}

Received: 26 January 2021; Revised: 25 May 2021; Accepted: 2 Juny 2021

\begin{abstract}
As a small island and tourist destination, Karimunjawa municipal is need fresh water to support the tourist activity, mainly to supply drinking water. Unfortunately, freshwater on a small island is obtained from groundwater which is very limited and vulnerable to climate change and anthropogenic activities. A groundwater assessment is necessary to receive up-to-date information on groundwater quality, to assess the groundwater feasibility for drinking water, and determine the pollutant source. The assessment was conducted by collected groundwater sampling from dug wells and swamp area in Karimunjawa municipal and then analyzed the samples in the laboratory to obtain the value of Nutrient $\left(\mathrm{NO}_{3}^{-}, \mathrm{NO}_{2}^{-}, \mathrm{NH}_{3}-\mathrm{N}\right)$; $\mathrm{Heavy} \mathrm{Metals}(\mathrm{Cu}$, Fe, and $\mathrm{Pb}$ ); and Salt (TDS, $\mathrm{Cl}^{-}, \mathrm{Na}^{+}$). These obtained parameters were compared with the quality standard of the minister of health regulation of the Republic of Indonesia about water quality standards for drinking water. In this study, 14 samples were collected and analyzed. The result shows that nutrient contaminant is low, but some groundwater sample was contaminated by ammonia. Heavy metal is undetectable, but almost all samples are contaminated by salt. Therefore, the groundwater in Karimunjawa municipal experienced seawater intrusion and not feasible to be consumed as drinking water.
\end{abstract}

Keywords: Groundwater quality, Karimunjawa municipal, groundwater pollution, seawater intrusion, small island.

Corresponding author:

Jl. Pasir Putih I Ancol Timur, Jakarta Utara 14430. Email: prihantono@gmail.com 


\section{INTRODUCTION}

Karimunjawa municipal is located in Karimunjawa Island. This island is categorized as a small island (UNESCO, 1991) because it has an area of approximately $46.24 \mathrm{Km}^{2}$ (Jepara Regency Statistic Agency, 2018). Karimunjawa Island is an important tourist destination in the province of Central Java in Indonesia due to this island has beautiful beaches and coral reefs. Furthermore, the Karimunjawa waters have good fishery resources because the primary productivity is high in this area (Nuzapril et al., 2019). Therefore, the local government is very active in promoting Karimunjawa to the public to visit this island. As a result, there was an increase in the number of tourists by $94.3 \%$ in Karimunjawa during $2013-2018$ (TIC Jepara Agency, 2019). Also, Based on Jepara Regency Statistics Agency (2013; 2018). In the same period, the number of homestays and hotels in Karimunjawa has increased $116.3 \%$.

With this potential, the fresh water is also needed to support tourism activities. In the other hand, freshwater on a small island is limited, and it relies on groundwater as a source of freshwater (Falkland, 1993). This groundwater is also vulnerable to climate change and anthropogenic activities and causes the groundwater quality is worse. Consequently, it cannot be consumed by humans due to polluted water as a source of various diseases (Halder \& Islam, 2015; Lu et al., 2015; Schmeller et al., 2018). Moreover, climate change impact, anthropogenic factors also cause a decrease in the amount and quality of groundwater. Human activities, such as domestic waste disposal without treatment (Geary \& Whitehead, 2013), sporadically extracting groundwater for household, agricultural, and tourism will increase severe groundwater amount and quality (Daskalaki \& Voudouris, 2008; Rauscher, 2007). Previous study by Hadi et al. (2006) showed that there was decreasing in groundwater quality which was caused by seawater intrusion in municipal areas.

Therefore, research and updating groundwater quality data are necessary to assess and monitor groundwater pollution in Karimunjawa municipal. Several methods can be applied to assess the groundwater quality, such as Groundwater Quality Index (GQI) (Saeedi et al., 2010); Metal Pollution Index (MPI) (Xiao et al., 2019); GALDIT (Chachadi \& LoboFerreira, 2001); and by comparing the value of the chemical parameters with water quality standards for human consumption (Geary \& Whitehead, 2013). Then, based on the assessment using these methods, the mitigation plan to prevent groundwater pollution should be determined.

In addition to groundwater, it is essential to support tourism activities, in particular, to supply drinking water in Karimunjawa municipal. Still, on the other hand, groundwater is also vulnerable to climate change and human activity itself. So, the assessment of groundwater quality is necessary to do. This paper aims to provide up-to-date information on the groundwater quality in the Karimunjawa municipal, assess the groundwater feasibility in Karimunjawa for consumption or drinking water, and determine the spatial pattern of groundwater quality degradation. Then, it can be determined where the source of the pollutants come from, and then this result can be used for groundwater mitigation in the Karimunjawa municipal.

\section{METHODOLOGY}

Karimunjawa municipal is located in Karimunjawa Island, Jepara Regency, Central Java Province, Indonesia. This island is located about $180 \mathrm{Km}$ North, offshore of Semarang city, the capital city of Central Java Province (Figure 1). This municipal has a flat

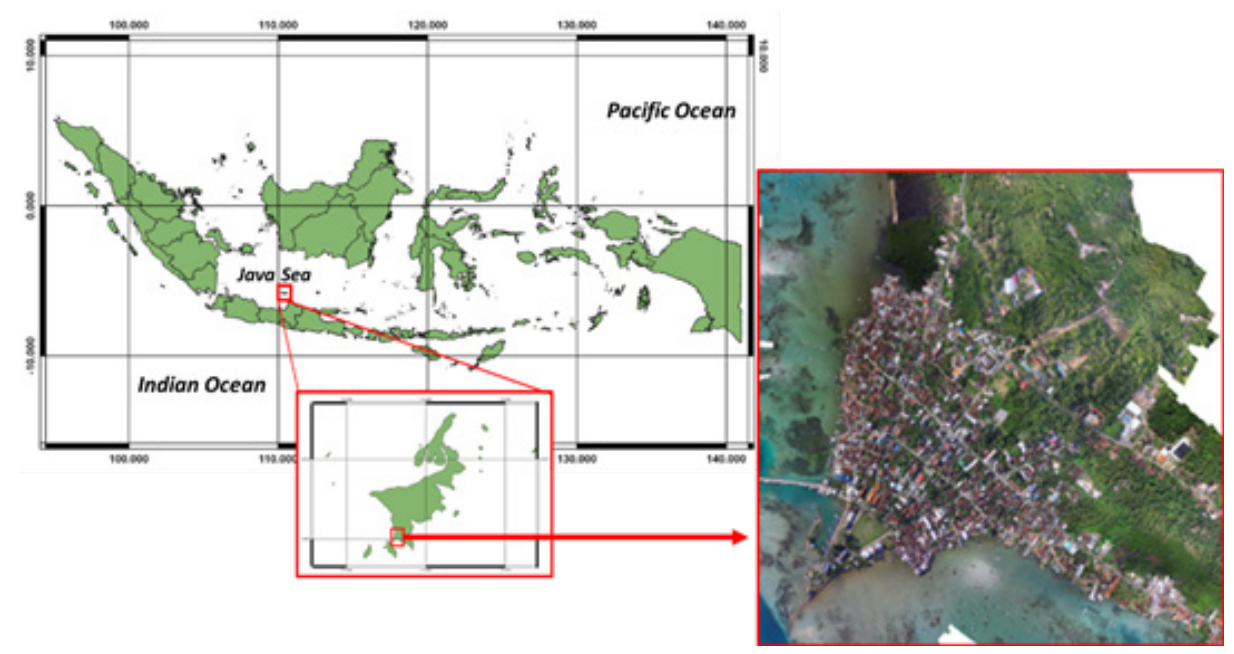

Figure 1. Karimunjawa municipal location. 
topography and lies on coastal alluvium, which consists of loose sand, swamp deposition, and partly of Karimunjawa formation (Hadi et al., 2006; Sidarto et al., 1993).

Groundwater assessment in Karimunjawa municipal was started by groundwater data collection. The data collection was conducted in October 2016 by taking groundwater samples from dug wells and swamps in Karimunjawa municipal that were suspected of being contaminated by domestic waste and seawater intrusion. Typically, in October, this island has a dry season, but it rained every day with medium intensity when the data were collected. The location of groundwater sampling was determined randomly, but its distribution covered the area of the municipal. The map of groundwater sampling points is shown in Figure 2.

Groundwater from the determined location was taken and stored in a 1-liter polyethylene bottle. Then, the bottle was held in a cool box that was already put ice inside to keep the chemical values stable. After that, the water samples were analyzed in the laboratory to obtain the chemical parameters such as nitrate $\left(\mathrm{NO}_{3}-\right)$, nitrite $\left(\mathrm{NO}_{2}\right)$, ammonia $\left(\mathrm{NH}_{3}-\mathrm{N}\right)$, chloride $(\mathrm{Cl})$, sodium $\left(\mathrm{Na}^{+}\right)$, total dissolve solid (TDS), copper $(\mathrm{Cu})$, iron $(\mathrm{Fe})$, and lead $(\mathrm{Pb})$.

Then, the results ere compared with the quality standard of the minister of health regulation of the Republic of Indonesia No. 492/Menkes/Per/IV/2010 about water quality standard for drinking water. Therefore, the groundwater pollution level in Karimunjawa municipal from contaminants such as nutrient $\left(\mathrm{NO}_{3}^{-}, \mathrm{NO}_{2^{-}}, \mathrm{NH}_{3}-\mathrm{N}\right)$; heavy metals $(\mathrm{Cu}, \mathrm{Fe}$, and $\mathrm{Pb}$ ); and salt (TDS, $\mathrm{Cl}^{-}, \mathrm{Na}^{+}$) should be known so that the groundwater feasibility for drinking water in Karimunjawa municipal can be determined.

Furthermore, for knowing the pollution pattern, the spatial distribution map of pollution should be known to determine the pattern of pollutant sources and the pollutant spread in Karimunjawa municipal. The spatial distribution map was created using the Kriging interpolation method and plotted using ArcGIS software.

\section{RESULTS AND DISCUSSION}

\section{Nutrient Contamination in Groundwater}

In this study, nutrient contamination in the groundwater is indicated by the concentration of nitrate, nitrite, and ammonia. The value of nutrient concentration from the analyzed groundwater samples in the laboratory is presented in Table 1 . There were 14 water samples obtained from the Karimunjawa municipal. Nutrient contamination is necessary to be known because nutrient contaminants show an indication of groundwater pollution due to domestic waste to the environment (Effendi, 2003).

Based on Table 1, all nitrite concentration values are below $0.003 \mathrm{mg} / \mathrm{l}$. It means that nitrite has not contaminated groundwater. On the other hand, the nitrate values in the obtained groundwater samples are ranged from $0.016-63.437 \mathrm{mg} / \mathrm{l}$. However, most of the nitrate values from the obtained samples are still appropriate with the quality standards. Only at point S011, the nitrate concentration value is $63.437 \mathrm{mg} / \mathrm{l}$,

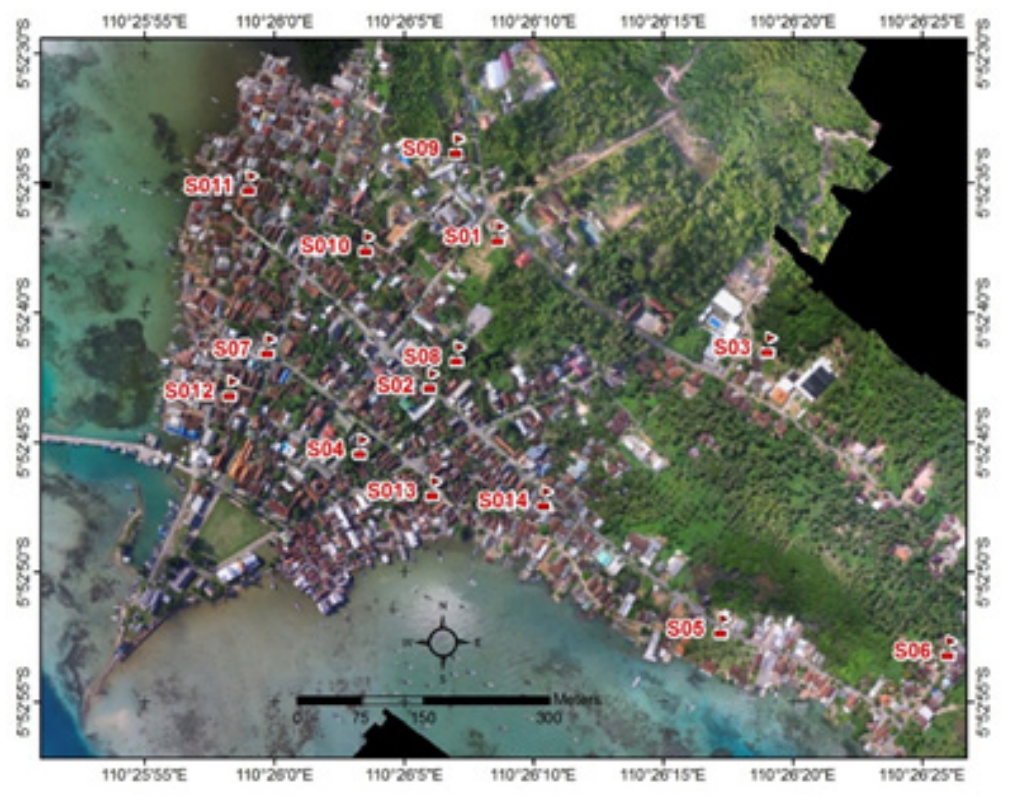

Figure 2. Groundwater sampling location. 
Table 1.

The concentration of Nitrate $\left(\mathrm{NO}_{3}^{-}\right)$, Nitrite (NO2-), Ammonia $\left(\mathrm{NH}_{3}-\mathrm{N}\right)$ in Karimunjawa municipal groundwater.

\begin{tabular}{llll}
\hline Point & $\mathrm{NO}_{3}-\mathbf{N}(\mathbf{m g} / \mathbf{l})$ & $\mathrm{NO}_{2}-\mathbf{N}(\mathbf{m g} / \mathbf{l})$ & $\mathbf{N H}_{3}-\mathbf{N}(\mathbf{m g} / \mathbf{l})$ \\
\hline S01 & 0.052 & $<0.003$ & 0.017 \\
S02 & 0.039 & $<0.003$ & 1.194 \\
S03 & 0.016 & $<0.003$ & 0.021 \\
S04 & 0.303 & $<0.003$ & 0.03 \\
S05 & 0.28 & $<0.003$ & 0.361 \\
S06 & 2,836 & $<0.003$ & 0.015 \\
S07 & 0.227 & $<0.003$ & 0.015 \\
S08 & 0.381 & $<0.003$ & 1,034 \\
S09 & 0.06 & $<0.003$ & 0.014 \\
S010 & 0.13 & $<0.003$ & 9.564 \\
S011 & 63.437 & $<0.003$ & 1.706 \\
S012 & 10.666 & $<0.003$ & 0.018 \\
S013 & 0.06 & $<0.003$ & 0.046 \\
S014 & 0.13 & $<0.003$ & 0.046 \\
\hline Quality & $\mathbf{5 0}$ & 3 & 1.5 \\
Standard & \multicolumn{3}{l}{} \\
\hline
\end{tabular}

and it exceeds the quality standard. Ammonia values in Table 1 range between 0.014-9.564 $\mathrm{mg} / \mathrm{l}$, and ammonia values that exceed the quality standard are at Point S010 and S011.

The spatial distribution of ammonia in Karimunjawa municipal is shown in Figure 3, which informs the ammonia pattern is dominant in residential areas near the west coast, with the highest value concentrated at point S010. This high ammonia value is consistent with nitrate values at Point S011, wherein these points' locations are close to each other. The value of nitrate and ammonia also exceeds the quality standard. This pattern is consistent with the ammonia pattern from the study conducted by Hadi et al. (2006).

According to Effendi (2003), nitrate levels that exceed $5 \mathrm{mg} / \mathrm{l}$ illustrate the occurrence of anthropogenic pollution from human activities (domestic waste) and animal feces. If humans consume groundwater with high nitrate concentration, it will cause health problems such as goiter and methemoglobinemia (Manampiring,

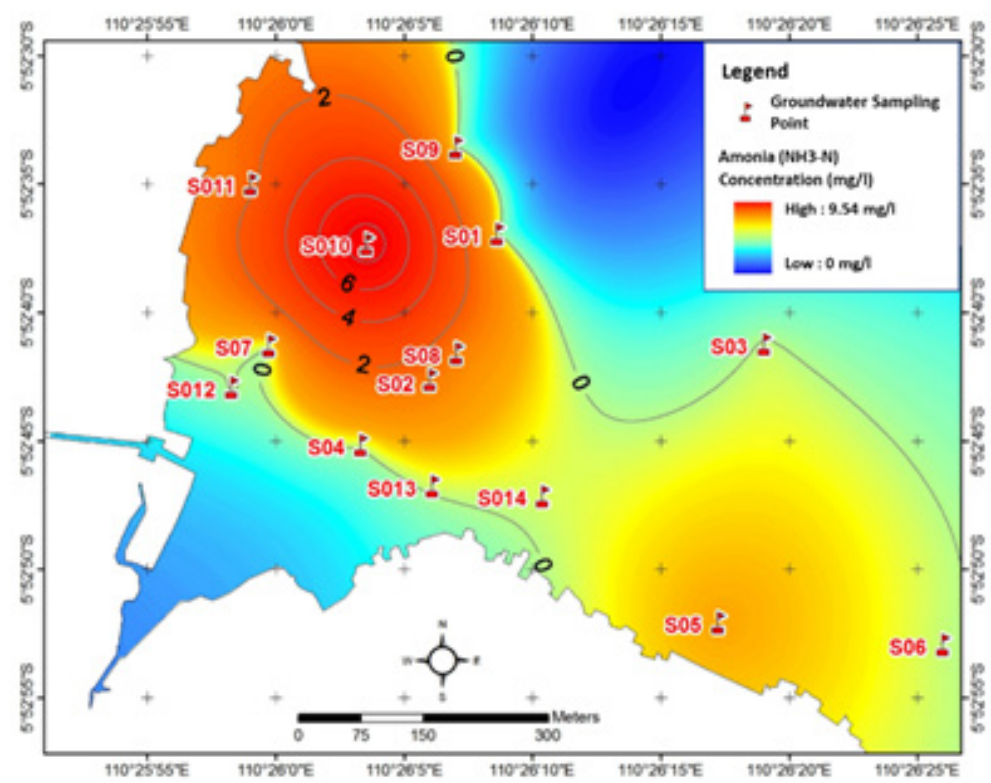

Figure 3. Spatial distribution map of ammonia $\left(\mathrm{NH}_{3}-\mathrm{N}\right)$ concentration in Karimunjawa municipal groundwater. 
2009).

Therefore, pollution due to nutrient contaminants in Karimunjawa municipal is still relatively low. However, this groundwater assessment result indicates groundwater pollution due to domestic waste disposal in the western part of the municipal.

\section{Heavy Metals Contamination in Groundwater}

Heavy metals at a certain level are hazardous for the human body because heavy metals have accumulated and poisoned the human body itself (Morais et al., 2012). Heavy metals in an environment are caused by natural and anthropogenic. Natural sources of heavy metals may come from natural weathering of the earth's crust and soil erosion. On the other hand, the anthropogenic source may from industrial discharge, urban runoff, and sewage effluents (Ming-Ho, 2005). In this study, the heavy metals copper, iron, and lead were analyzed to assess heavy metal contamination in Karimunjawa municipal groundwater. The obtained heavy metals value can be seen in Table 2.

Based on Table 2, The value of copper in Karimunjawa municipal groundwater has a minimal value of less than $0.004 \mathrm{mg} / \mathrm{l}$, as well as a Lead value with a concentration of less than $0.03 \mathrm{mg} / \mathrm{l}$, or in other words, these heavy metals are undetectable, and copper and lead do not pollute the groundwater. Copper and Lead can be released from the burning of fuel, wearing tires, leakage of oils, and corrosion of batteries and metallic parts such as radiators (Baker et al., 2007). These activities may be found in the dockyard and mechanical workshop. Even though in Karimunjawa municipal, there is fishing boat activity in the port, this activity is relatively low, and the contribution of pollution to heavy metal in groundwater is small.

The concentration of Iron in the Karimunjawa municipal groundwater ranges from 0.024 to 0.236 $\mathrm{mg} / \mathrm{l}$. It is below the quality standards by the Minister of Health Regulation (2010). The iron can be released from anthropogenic sources, such as the iron and steel industry, sewage, and dust from iron mining (Reimann \& Caritat, 1998). It is also from fertilizer and herbicide (Reimann et al., 2003).

The pattern of Iron distribution of groundwater (Figure 4) shows that high iron concentrations are in the south region of municipal with the highest value at point S05. High iron content can be caused by oxidation of the iron compounds involved (Garba \& Abubakar, 2018).

Based on the results described above, in general, groundwater in Karimunjawa is not polluted yet by heavy metals. In Karimunjawa municipal, there are no industries, mechanical workshops, and mining activities even though regulation from the government is necessary to prevent groundwater pollution from heavy metals.

\section{Salt Contamination in Groundwater}

In this study, salt contamination in groundwater was analyzed using sodium, chloride, and TDS in the Karimunjawa municipal groundwater. The seawater intrusion can be determined by analyzing the salt contamination in groundwater because sodium and chloride are the most considerable seawater content. The sodium, chloride, and TDS obtained from the

Table 2.

The Concentration of Copper $(\mathrm{Cu})$, Iron $(\mathrm{Fe})$, and Lead $(\mathrm{Pb})$ in Karimunjawa Municipal Groundwater.

\begin{tabular}{llll}
\hline Point & $\begin{array}{l}\text { Copper }(\mathrm{Cu}) \\
(\mathbf{m g} / \mathbf{l})\end{array}$ & $\begin{array}{l}\text { Iron (Fe) } \\
(\mathbf{m g} / \mathbf{l})\end{array}$ & $\begin{array}{l}\text { Lead }(\mathrm{Pb}) \\
(\mathbf{m g} / \mathbf{l})\end{array}$ \\
\hline S01 & $<0.004$ & 0.056 & $<0.03$ \\
S02 & $<0.004$ & 0.077 & $<0.03$ \\
S03 & $<0.004$ & 0.025 & $<0.03$ \\
S04 & $<0.004$ & 0.125 & $<0.03$ \\
S05 & $<0.004$ & 0.236 & $<0.03$ \\
S06 & $<0.004$ & 0.063 & $<0.03$ \\
S07 & $<0.004$ & 0.065 & $<0.03$ \\
S08 & $<0.004$ & 0.112 & $<0.03$ \\
S09 & $<0.004$ & 0.027 & $<0.03$ \\
S010 & $<0.004$ & 0.055 & $<0.03$ \\
S011 & $<0.004$ & 0.031 & $<0.03$ \\
S012 & $<0.004$ & 0.028 & $<0.03$ \\
S013 & $<0.004$ & 0.024 & $<0.03$ \\
S014 & $<0.004$ & 0.037 & $<0.03$ \\
\hline Quality 2 & $\mathbf{0 . 3}$ & $\mathbf{0 . 0 0 1}$ & \\
Standard & & & \\
\hline
\end{tabular}




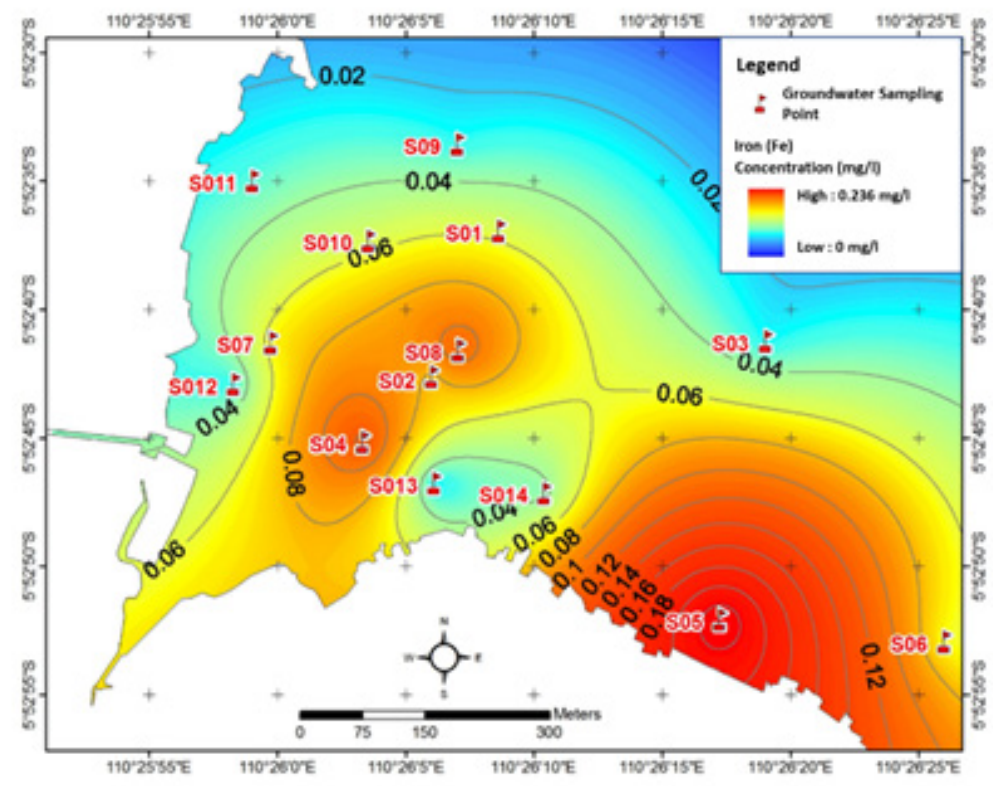

Figure 4. Spatial distribution map of Iron (Fe) concentration in Karimunjawa municipal groundwater.

laboratory are presented in Table 3. According to the Minister of Health Regulation (2010), the concentration of chloride allowed for drinking water must not exceed $250 \mathrm{mg} / \mathrm{l}$, Sodium must not exceed $200 \mathrm{mg} / \mathrm{l}$, and TDS must not exceed $500 \mathrm{mg} / \mathrm{l}$. In Table 3, the salt concentration, which exceeds the quality standard, is a highlight with yellow color.

The obtained result of sodium content in the groundwater ranged from $2.73-284.63 \mathrm{mg} / \mathrm{l}$. Based on Table 3, Point S04, S05, S08, S013 have a value of Sodium that exceeds the Minister of Health Regulation (2010). The spatial distribution of sodium concentration in the groundwater is presented in Figure $5 \mathrm{a}$. This figure shows that the highest sodium concentration is in the south region of Karimunjawa municipal, dominant at points S05 and S013. Also, it is concentrated in the middle area of Karimunjawa municipal, near the Garbage Disposal Site at Point S08, and higher concentrations appear on the west coast of

Table 3.

The Concentration of total Dissolve Solid (TDS), Sodium (Na), and Chloride (Cl) In Karimunjawa Municipal Groundwater.

\begin{tabular}{llll}
\hline Point & TDS (mg/l) & Na (mg/l) & Cl (mg/l) \\
\hline S01 & 392 & 104.49 & 23.03 \\
S02 & 246 & 161.07 & 29.76 \\
S03 & 204 & 4.82 & 9.38 \\
S04 & 1,032 & 263.69 & 38.73 \\
S05 & 5,580 & 284.63 & 898.93 \\
S06 & 582 & 80.74 & 64.41 \\
S07 & 500 & 87.65 & 22.42 \\
S08 & 922 & 273.14 & 88.06 \\
S09 & 156 & 2.73 & 13.05 \\
S010 & 600 & 112.27 & 24.46 \\
S011 & 800 & 194.33 & 43.62 \\
S012 & 438 & 89.38 & 18.35 \\
S013 & 1,040 & 275.5 & 86.43 \\
S014 & 478 & 85.92 & 17.12 \\
\hline Quality & $\mathbf{5 0 0}$ & $\mathbf{2 0 0}$ & $\mathbf{2 5 0}$ \\
Standard & \multicolumn{3}{l}{} \\
\hline
\end{tabular}



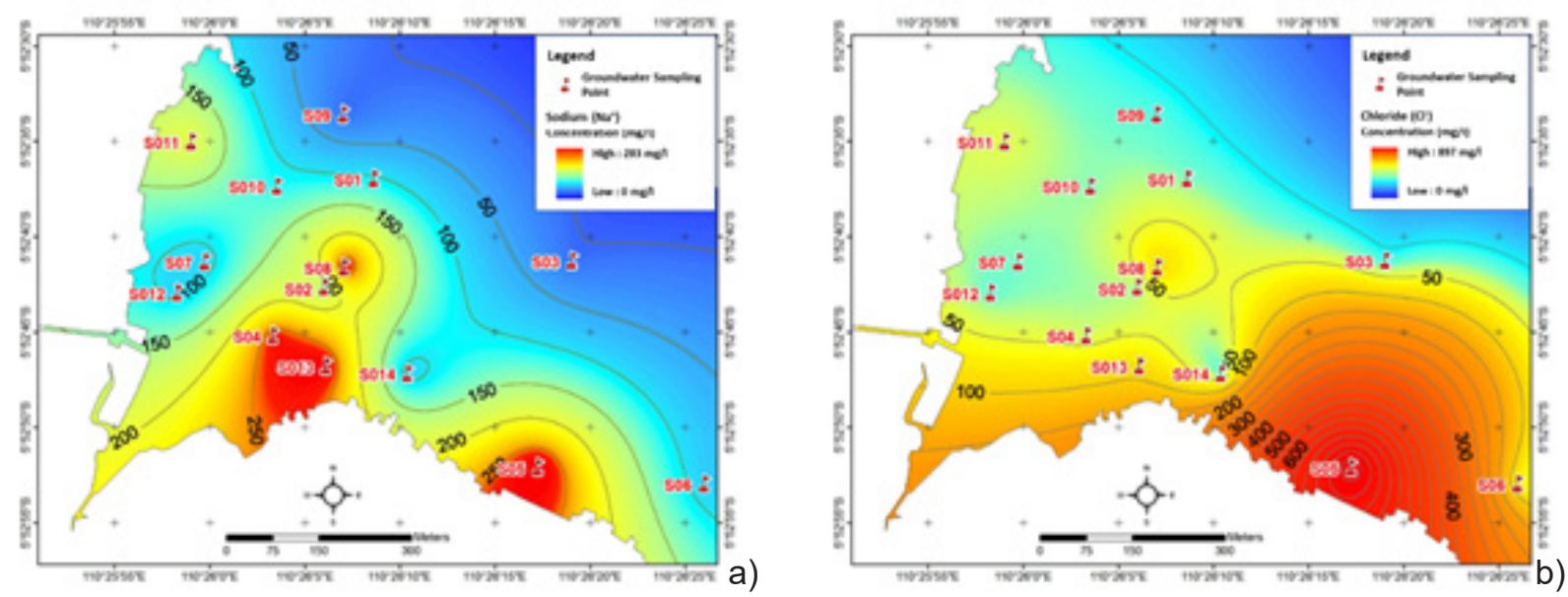

Figure $5 . \quad$ a) Spatial distribution map of sodium $(\mathrm{Na})$ and b) chloride $(\mathrm{Cl})$ concentration in Karimunjawa municipal groundwater.

Karimunjawa municipal at point S011, even though point S011 is still below the quality standard, but it has a high concentration.

Furthermore, chloride concentration in the groundwater ranged from 9.38 - $898.93 \mathrm{mg} / \mathrm{l}$. chloride concentration that exceeds the quality standard quality standards of the Minister of Health Regulation (2010) is S05. Figure $5 \mathrm{~b}$ shows the distribution of Chloride in the groundwater in the Karimunjawa municipal. The Chloride has a high concentration on the southern coast of Karimunjawa municipal, with the highest point is at point $\mathrm{S} 05$.

TDS concentration in the groundwater range from 156 - $5580 \mathrm{mg} / \mathrm{l}$. The TDS distribution pattern in the Karimunjawa municipal can be seen in Figure 6, where the dominant TDS distribution pattern is located in the south region of the municipal (Point S05). TDS concentrations that exceed the quality standard of the Minister of Health Regulation (2010) are at stations S04, S05, S06, S08, S010, S011, S013. The high TDS concentration in the Karimunjawa municipal groundwater may be caused by seawater intrusion and household waste.

Based on the result of the spatial distribution map, the spatial map distribution of sodium (Figure $5 a$ ), chloride (Figure 5b), and TDS (Figure 6) have a similar distribution pattern. The pattern shows that the high concentration of salt distribution dominant in the south region (at point S05 and S013), middle region (at point S08), and west region (at point S011). These distribution patterns indicate seawater intrusion

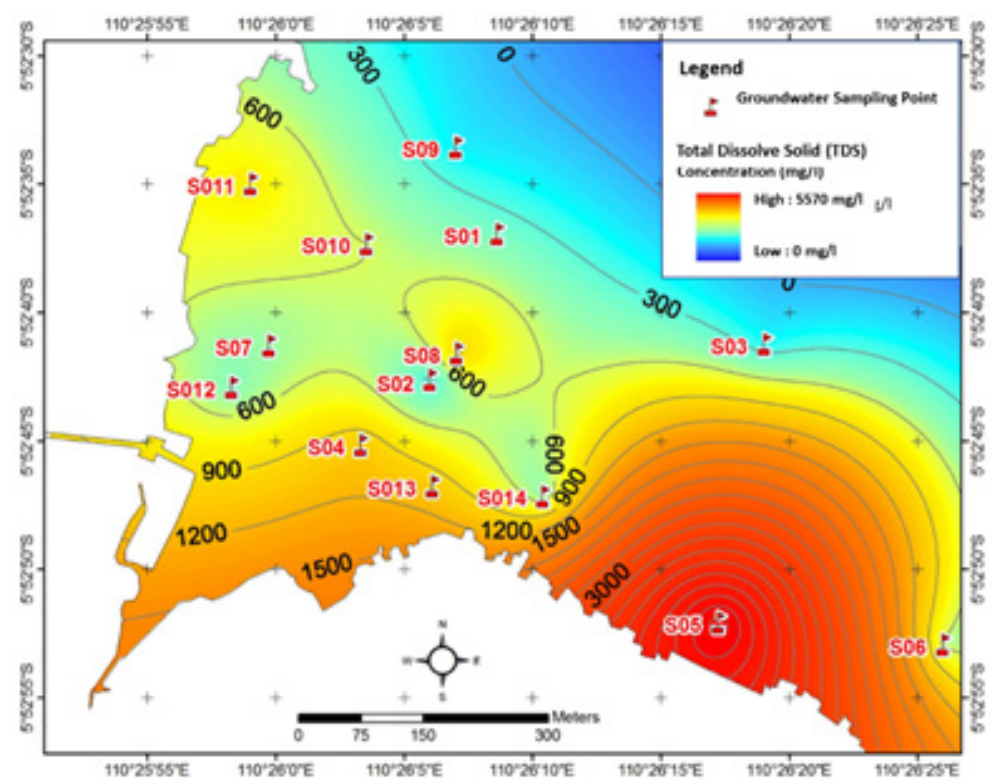

Figure 6. Spatial distribution map of TDS concentration in Karimunjawa municipal groundwater. 
into groundwater in the Karimunjawa municipal from the south and west regions. This phenomenon may occur because the fresh groundwater head level in Karimunjawa municipal is lower than the seawater level and enhanced by the high sediment porosity in Karimunjawa municipal that consists of loose sand on coastal alluvium.

The salt contaminant occurs in the beach area and the middle region of the Karimunjawa municipal. Still, the pattern is not symmetric, and this area is relatively apart from the south and west part. The possibility of explaining this phenomenon is the drainage channels connecting the swamp and the sea to prevent floods in Karimunjawa municipal. When the sea was tidal at the highest level, the seawater enters the swamp area (Hadi et al., 2016) through the drainage channel and mixes with swamp water, then this water seeps into the ground and contaminates the groundwater.

Thus, the groundwater in Karimunjawa municipal has been polluted by the salt contaminant due to seawater intrusion. Consequently, seawater intrusion is the main problem for the groundwater in Karimunjawa municipal because most of the samples exceed the Minister of Health Regulation (2010). Therefore, generally, groundwater in Karimunjawa municipal is not feasible to consume as drinking water.

\section{CONCLUSION}

Based on this assessment, the groundwater in Karimunjawa is not feasible to be consumed as drinking water. It has been polluted by seawater intrusion indicated by the exceeding concentration of sodium, chloride, and TDS. The region that experiences a high concentration of seawater intrusion occurred in the southern and western areas of Karimunjawa municipal. However, in the middle part of the municipal, there is also an increase in salt concentration. It may occur because the seawater enters the swamp area through the drainage channel, which is lower than the seawater level when at high tide. In consequence, seawater may enter the swamps and seeps into the surrounding groundwater.

Although groundwater pollution due to nutrient and heavy metal parameters is not so dominant, some of the samples in the municipal area show ammonia concentration that exceeds the quality standard. This finding cannot be ignored; otherwise, ammonia pollution may be worse in Karimunjawa municipal. Therefore, a mitigation action to prevent groundwater pollution in Karimunjawa municipal is necessary to issue a regulation for waste handling by the local government.

Although this study revealed groundwater quality and pollution sources spatially, research on human behavior has not been conducted. Research in human behavior such as domestic waste disposal and groundwater extraction by the municipal citizen is necessary to predict the groundwater quality in the future and its mitigation action.

\section{ACKOWLEDGEMENTS}

This work was carried out with funding from the Marine Research Center, Ministry of Marine Affairs and Fisheries, DIPA 2016. The authors thank Muhammad Azzamudin and Ariansyah for their help in data collection. The paper contributes to local government, local people, and stakeholders who have the authority in planning and managing the Karimunjawa municipal. The main contributors of this article is Joko Prihantono.

\section{REFFERENCE}

Baker, L.R., Hozalski, R., \& Gulliver, J.S. (2007). An Assessment Of Stormwater Best Management Practices, Ed. J. S. Gulliver And J. L. Anderson. St Paul Mn, University Of Minnesota.

Chachadi, A, G., \& Lobo-Ferreira, J, P.(2001). Seawater intrusion vulnerability mapping of aquifers using GALDIT method. Proc. Workshop on modelling in hydrogeology, Anna University, Chennai, pp.143 156, and in COASTIN A Coastal Policy Research. Newsletter, Number 4, March 2001. New Delhi, TERI, pp 7-9.

Daskalaki, P., \& Voudouris, K. (2008). Groundwater quality of porous aquifers in Greece: A synoptic review. Environmental Geology, 54(3), 505-513. https://doi.org/10.1007/s00254-007-0843-2

Effendi. (2003). Telaah Kualitas Air. Yogyakarta. Kanisius.

Falkland, A.C. (1993). Hydrology and water management on small tropical islands. Hydrology of Warm Humid Regions. Proc. International Symposium, Yokohama, 1993, (216), 263-303.

Garba, S., \& Abubakar, M. (2018). Source and Distribution of The Heavy Metals: $\mathrm{Pb}, \mathrm{Cd}, \mathrm{Cu}$, $\mathrm{Zn}, \mathrm{Fe}, \mathrm{Cr}$, and $\mathrm{Mn}$ in Soils of Bauchi Metropolis, Nigeria. American Journal of Engineering Research (AJER), 7(2), 13-22.

Geary, P.M., \& Whitehead, J.H. (2013). Groundwater Contamination From on-Site Domestic Wastewater Management Systems in a Coastal Catchment. (March 2001). https://doi. org/10.13031/2013.6055 
Hadi, S., Arsadi, E. M., Hartanto, P., \& Marganingrum, D. (2006). Kualitas Air Tanah Bebas Kota Karimunjawa, Pulau Karimunjawa. RISET Geologi Dan Pertambangan, 6(2), 13-34.

Halder, J., \& Islam, N. (2015). Water Pollution and its Impact on the Human Health. Journal of Environment and Human, 2(1), 36-46. https://doi. org/10.15764/eh.2015.01005

Jepara Regency Statistics Agency. (2013). Karimunjawa sub-district in Number 2013 (Kecamatan Karimunjawa dalam Angka 2013). url : https://jeparakab.bps.go.id/publication/2014/ 02/25/88c633ca16695d55c3650be2/kecamatankarimunjawa-dalam-angka-2013.html

Jepara Regency Statistics Agency. (2018). Karimunjawa sub-district in Number 2013 (Kecamatan Karimunjawa dalam Angka 2013). url : https:// jeparakab.bps.go.id/publication/2018/09/26/ b0ca4b5d4f09ddb2701c9c72/kecamatankarimunjawa-dalam-angka-2018.html

Lu, Y., Song, S., Wang, R., Liu, Z., Meng, J., Sweetman, A.J., \& Wang, T. (2015). Impacts of soil and water pollution on food safety and health risks in China. Environment International, 77, 5-15. https://doi. org/10.1016/j.envint.2014.12.010

Manampiring, Aaltje E. 2009. Studi Kandungan Nitrat (NO-3) Pada Sumber Air Minum Masyarakat Kelurahan Rurukan Kecamatan Tomohon Timur Kota Tomohon. Karya Tulis IImiah. Fak. Kedokteran Universitas Sam Ratulangi, Manado.

Ming-Ho, Y. (2005). Environmental Toxicology: Biological and Health Effects of Pollutants, Chap. 12, CRC Press LLC, ISBN 1-56670-670-2, 2nd Edition, Boca Raton, USA. (18) (PDF) Heavy Metals and Human Health. Available from: https:// www.researchgate.net/ publication/221923928 Heavy_Metals_and_Human_Health [accessed Jan 27 2020].

Minister of Health Regulation of Republic Indonesia. (2010). Quality Standard for Drinking Water Regulation. Permenkes No. 492/MENKES/PER/ IV/2010. Ministry of Health of Republic Indonesia.

Morais, S., Costa, F. G. e, \& Lourdes Pereira, M. de. (2012). Heavy Metals and Human Health. In J. Oosthuizen (Ed.), Environmental Health Emerging Issues and Practice (pp. 227-246). https://doi.org/10.5772/29869

Nuzapril, M., Susilo, S.B., \& Panjaitan, J.P. (2019). Distribution of Primary in Productivity Relation with The Water Quality Condition in Karimunjawa Waters. Jurnal Segara, 15(1), 9-17. DOI: http:// dx.doi.org/10.15578/segara.v15i1.7559

Rauscher, M. (2007). Dynamics of agricultural groundwater extraction: Comment and correction. Ecological Economics, 61(1), 11-14.https://doi. org/10.1016/j.ecolecon.2006.12.005

Reimann, C., \& Caritat, P.de. (1998). Chemical elements in the environment-factsheets for the geochemist and environmental scientist. Berlin, Germany7 Springer-Verlag, 1998.

Reimann, C., Siewers, U., Tarvainen, T., Bityukova, L., Eriksson, J., \& Gilucis, A., (2003). Agricultural Soils in Northern Europe: A Geochemical Atlas. Geologisches Jahrbuch, Sonderhefte, Reihe D, Heft SD 5, Schweizerbart'sche Verlagsbuchhandlung, Stuttgart.

Saeedi, M., Abessi, O., Sharifi, F., \& Meraji, H. (2010). Development of groundwater quality index. Environmental Monitoring and Assessment, 163(1-4), 327-335. https://doi.org/10.1007/ s10661-009-0837-5

Schmeller, D.S., Loyau, A., Bao, K., Brack, W., Chatzinotas, A., De Vleeschouwer, F., ... Vredenburg, V. T. (2018). People, pollution, and pathogens - Global change impacts in mountain freshwater ecosystems. Science of the Total Environment, 622-623, 756-763. https://doi. org/10.1016/j.scitotenv.2017.12.006

Sidarto, S. Santosa., \& Hermanto, B. (1993). Peta Geologi Lembar Karimunjawa, Jawa. Peta Skala 1: 100.000. Puslitbang Geologi. Bandung

Tourist Information Centre (TIC) Jepara Regency Agency. (2019). Tourist visit in Jepara Residence Statistic. URL: http://tic.jepara.go.id/kumpulanberita/itemlist/category/18-statistik

UNESCO. (1991). Hydrology and Water Resources of Small Islands, a Practical Guide. Prepared by A. Falkland (ed.) \& E. Custodio with contributions from A. Diaz Arenas \& L. Simler and case studies submitted by others. Studies and Reports on Hydrology No. 49, Paris, France.

Xiao, K., Li, H., Shananan, M., Zhang, X., Wang, X., Zhang, Y., ... Liu, H. (2019). Coastal water quality assessment and groundwater transport in a subtropical mangrove swamp in Daya Bay, China. Science of the Total Environment, 646, 1419-1432. https://doi.org/10.1016/j.scitotenv.2018.07.394 
